\title{
Beowulf (2013 [2020]) as a graphic novel: An interview with Santiago García and David Rubín ${ }^{1}$
}

\author{
Jorge L. Bueno Alonso \\ University of Vigo
}

Visualizing Beowulf has always been problematic, which is a paradox in itself taking into account the highly visual power the Old English epic poem holds. As far as films are concerned, we are still waiting for "a full-length Beowulf film that actually sticks pretty closely to the poem” (Haydock \& Risden 2013: 186). We have been pretty much luckier in the realm of graphic novels; as Stephen E. Tabachnik (2017: 2) has very properly pointed out, graphic novel adaptation of literary texts

is another area in which the new form has proven itself. There are superb adaptations of Homer, Beowulf, Shakespeare, Poe, Moby Dick, The Picture of Dorian Gray, Conrad, Proust, Kafka, among many, many others. The use of such adaptations in the classroom along with the originals prompts enthusiastic discussion of what, if anything, has been changed or not changed in the adaption, and what such adaptation can bring to the interpretation of the original texts.

Beowulf never ceased to attract the attention of many talented graphic and visual artists that wanted to put the Beowulf tale back in its oral context, though these days that context belongs to the new visual orality of our early $21^{\text {st }}$-century mass culture, this "new civilization of the vision similar to the one experienced by medieval people when contemplating the images at their cathedrals (Eco 1999: 332)". After a very highly hypersexualized mainstream beginning (Bueno 2021:

\footnotetext{
${ }^{1}$ Research made to write this interview was funded by the Galician Autonomous Goverment (Plan de Axudas para a consolidación e estruturación de grupos de referencia competitiva do Sistema Universitario Galego, grant number ED431C 2021/52). This grant is hereby gratefully acknowledged.
}

Jorge L. Bueno Alonso, Selim26 (2021): 151-166.

ISSN 1132-631X / ISSN-L 2792-3878 / https://doi.org/10.17811/selim.26.2021.151-166 
55-57), I have recently stated (Bueno 2020, 2021) how there is a great deal of critical consensus in signaling out two graphic novels as the best Beowulfian adaptations produced so far: Hinds (2007) and García \& Rubín (2013).

Originally published in Spanish by Astiberri in 2013, the English translation by Image Comics in 2016 really boosted the worldwide praise of this great graphic novel, which is a real feast for the senses and made Beowulf available to many readers for the first time. It received an Eisner Award nomination for Best Adaptation from Another Medium in 2018. ${ }^{2}$

With the recent publication of the graphic novel's third edition (2020), I approached García and Rubin for an interview about their wonderful and inspiring take on Beowulf, which they heartily embraced. The interview was pandemically conducted through a questionnaire I devised and several online conversations through Twitter between November 2020 and May 2021. They had liberty to interrupt or complement each other and to address issues or eschew questions at will. What follows is a transcription of our discussion, edited for publication.

\section{How did the project come out? What idea did you have in mind?}

Santiago García (SG): In my case the project arises in childhood. My uncle had an illustrated book called Myths and Legends, in which Anne Terry White ${ }^{3}$ glossed stories from all cultures, from Pandora's Box or Icarus to Roncesvalles or the Nibelungs. Beowulf was among them and it always fascinated me. The magnificent illustrations by Alice and Martin Provensen were even more important to me. When I started making adult comics, Beowulf was one of the stories that I had dragged on for the longest time. In fact, one of my first projects

\footnotetext{
${ }^{2}$ To see a real example that highlights Tabachnik's aforementioned statement, "Another Medium" that year meant "Literature", as all nominees were adaptations from literary works: Beowulf, adapted by Santiago García \& David Rubín (Image); H. P. Lovecraft's The Hound and Other Stories, adapted by Gou Tanabe, translated by Zack Davisson (Dark Horse); Herman Melville's Moby Dick, adapted by Christophe Chabouté, translated by Laure Dupont (Dark Horse); and Kindred, by Octavia Butler, adapted by Damian Duffy \& John Jennings (Abrams ComicArts), which won the award.

${ }^{3}$ Santiago García refers to the Spanish translation of The Golden Treasury of Mytbs and Legends, adapted from the World's Great Classics by Anne Terry White. Illustrated by A. \& M. Provensen. 164 pp. New York, Golden Press, 1959. In Spanish it was published as Mitos y Leyendas. El Gran Libro de Oro. Valencia, Ediciones Gaisa S.L., 1968.
} 
was to make Beowulf with Javier Olivares. We were working on it for years until we finally gave up. When I publicly announced that we had abandoned that endeavor, David Rubín immediately offered to take it up again. We put the whole project back together with David and started over. David's arrival not only saved Beowulf; it was an injection of vitality and a boost that helped me a lot in my career.

David Rubín (DR): In my case, it was when Santiago announced that he and Javier Olivares were leaving their Beowulf project, after ten years working on it. It was a poem that I had been wanting to read for years, so it annoyed me quite a bit to see that all this was going to come to nothing and, without giving it much thought, I contacted Santiago and suggested that I could draw it.

What is the reason, in your opinion, of the graphic novel's great reception? Three editions are uncommon for such a topic. It was not an excessively popular subject matter when the first edition came out in the USA, and in Spain the main American versions were virtually unknown and remained untranslated. Was this 'ignorance' something that your work benefitted from? Was it a kind of success that spread through the reading public by word of mouth due to the power of your take on the story?

SG: David's work was spectacular and broke the mold at the time. It was an easy-to-read, very visually enjoyable comic and our audience needed something like that to confirm that the Spanish graphic novel, which was beginning to consolidate itself at that time, had more breadth and scope than some thought.

DR: When our Beowulf came out, at the end of 2013, there was nothing in the world of comics remotely similar to it. It is a work with some Sword \& Sorcery elements but it does not belong to such genre. It shows rawness with no frills, no flourish, no pretty armor and magic swords. It is epic, but it does NOT drink from traditions of the genre such as Heavy Metal music and its aesthetics, Conan, The Lord of the Rings or Game of Thrones; many people who liked that kind of thing enjoyed our Beowulf for that reason. At the same time, readers who would never read a Conan comic book, even with a gun to their heads, enjoyed our graphic novel because it offered new approaches that other works, more faithful to the canons established by the Sword \& Sorcery genre, could never provide. Preparing the promotion of the work well in advance (more than a year or so) also helped a lot in its positive reception. We showed snippets of 
the work in progress and kept a growing mass of readers interested in its development. That was increasing the hype, and it really exploded when Beowulf reached bookstores and people found the volume (which in itself as an object oozed epic character) standing out on the shelves.

To develop the script, you freely worked on the text to capture your vision of the story. Textually speaking, you mentioned Heaney's translation (1999) as a starting point. How much of Heaney structure-wise is contained in your own text? Have you read or consulted any other translation/version?

SG: As I said earlier, what I really wanted to do was a version of the Beowulf story from Myths and Legends. To me, that was the story, with the decisions and selections previously made by Anne Terry White. From then on, I used versions like Seamus Heaney's to complete, expand and adapt on my own, as well as to get closer to the language more directly. This was something of special interest to me, as I was highly influenced by Jorge Luis Borges' take on the Icelandic sagas I read as a teenager.

DR: Scriptwise, Santiago and I talked a lot before we started producing the work. There was a huge pre-production stage to lay the foundations for the new approach we wanted to give to our Beowulf. The only condition I demanded from Santiago when I accepted the project was that I wanted him to rewrite it. I didn't want it to be "Santiago García's and Javier Olivares' Beowulf", drawn by David Rubín. I wanted the story to be our own: García \& Rubín’s.

As far as the standard threefold division of the poem is concerned, I particularly enjoyed the fact that you avoided the "Monster, Mother, Dragon" classic commonplace to present a much more interesting "A Monster, Mother, Another Monster". Was this always clear for you both? What was your intention, if any?

SG: To me, the Dragon has always been a repetition, like the coda in a poem that is there to remind you that the monster you thought to have slain is still alive. It may be a different monster altogether, but the fight will never be over until our death. And even so, remembrances will remain and the story will be there to be retold. I mean, I am not interested in the peculiarities that make 
Grendel, his mother, and the Dragon different monsters; I am way more into signaling out what makes them a similar thing from Beowulf's perspective.

DR: In my opinion, this approach we took was a total success. It makes everything wilder, more direct.

Visually speaking, how would you frame your own work in the overall context of Beowulf and graphic novels? I always thought that your proposal, genuine as it is, is closer to Gareth Hinds' and very far away from more standard (Storrie \& Randall 2008) or neonoir/neogothic approaches (Stern \& Steininger 2007). It is a 100\% García \& Rubin.

SG: David creates his own universe. The book is filled with original visual findings. I know David did not revise prior versions of Beowulf. His points of reference were more linked to certain videogames or specific films, like Nicolas Winding Refn's Valballa Rising (2009). This only means he used these references to get his own inspiration when creating the aesthetic frame he looks for. There are no specific things taken from these works.

DR: I haven't seen much of prior adaptations of the story, but I liked what I have seen so far. I never had those versions in mind, though, nor did I consider the Sword \& Sorcery genre, the stories of Conan, or similar stuff. In fact, as I hinted before, I think our Beowulf do not belong to the Sword \& Sorcery genre, or to Fantasy as such. I have always considered Beowulf as a kind of Western, a 'Death of the Old West' kind of story, with heroes mourning a way of life that fades never to return; heroes and monsters, anyhow. As Santiago mentioned, my main inspirational sources were Nicolas Winding Refn's Valballa Rising (2009), Hidetaka Miyazaki's Demon's Souls videogame (2009, From Software), and the pictorial style of Jackson Pollock and Francis Bacon.

You bave used a wide variety of panel dispositions, playing wildly with the scene as a whole and constant close-up details — as in Beowulf's arrival to Heorot, the feast with Unferth's provocation, or Grendel's entrance at Heorot (Figure 1) - or with two parallel actions (as in the Breca / Beowulf digression or Beowulfs funeral). Did you have these visual cues clear beforehand? To me this technique gave you a magnificent way of translating very effectively the narrative complexity of the poem without abandoning your own signature style. There are things from Ether (with Matt Kindt, $2017,2019,2020)$ or The Hero $(2011,2012)$ that would fit here. 


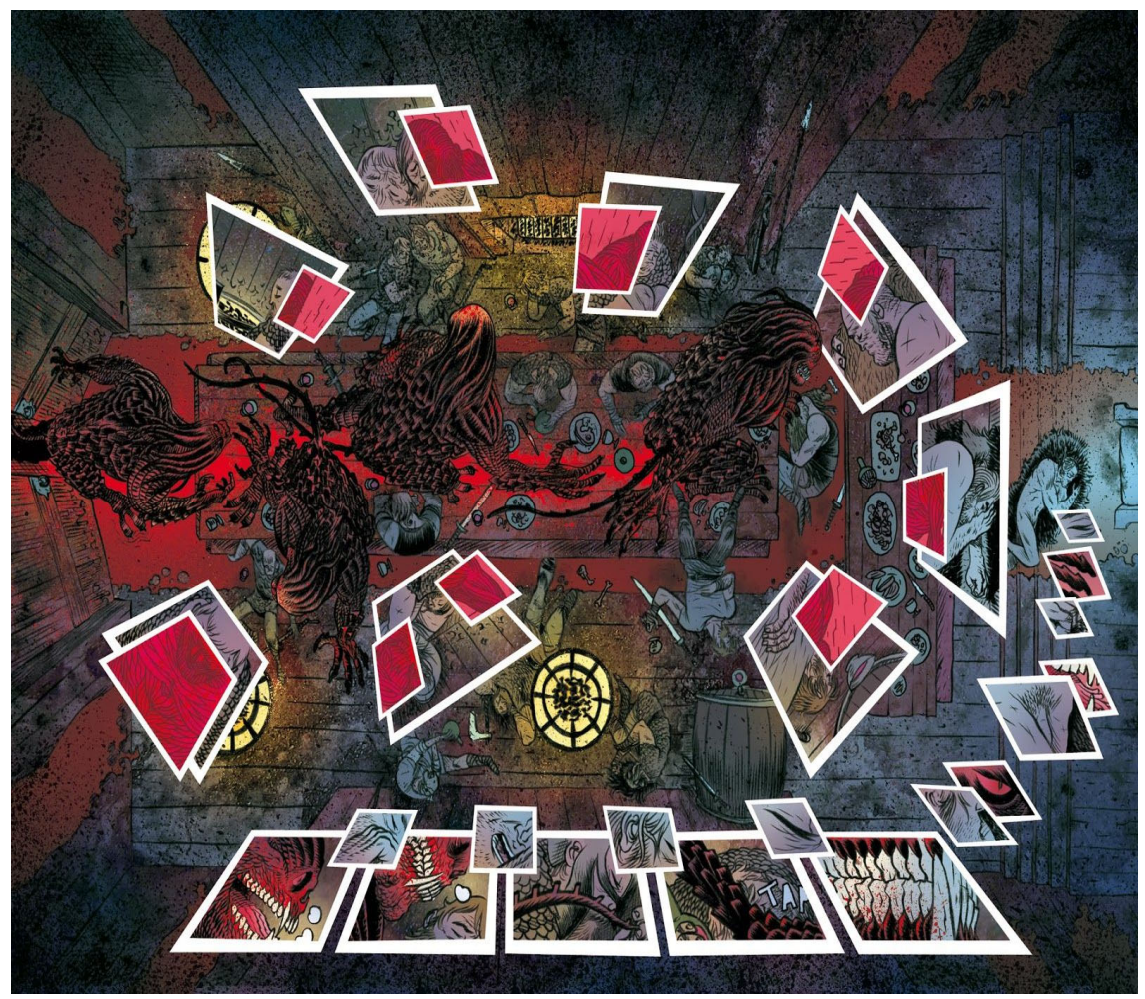

Figure 1. Grendel's entrance in Heorot ${ }^{4}$

SG: I think David never stopped developing his style from his early days onwards. Every new project took him several steps ahead. In Beowulf there are elements he already added to The Hero, and it is also normal to find in later works — such as Ether — things he began using in Beowulf. David, as an author, never adjusted to one single functional style. He is in constant evolution.

DR: How you tell a story is always the key aspect to me. Every story requires a specific, singular approach. The Hero is a very pop graphic novel, almost a comic book version of a Rock Opera. Ether is a Sci-Fi / Fantasy story, but very pop

${ }^{4}$ All excerpts from Beowulf (C) by Santiago García and David Rubín are reproduced by permission of the authors. 
too. Every work demands a reshaping of the way you understand and implement your work depending on where you want to get at with the story. In Beowulf I tried to go directly to the heart of the matter, to reach the marrow in a single stroke; it was a much drier and harder approach, more forceful and less reminiscent or supported by winks to other genres or works that may have influenced you as an artist; it is written and drawn with the guts. In each new work I try to experience new things with a double aim in mind: the reader has to enjoy it more, and I don't want to get bored doing it. Here the challenge I accepted was to play with the narrative to be able to show different moments in different time or space, in an overlapping structure, but when reading it, readers had to read it in succession, without asking questions that hinder their reading. I think the great success of our Beowulf is that it is a tremendously complex comic to execute, but very simple and natural when it comes to reading it.

In terms of character composition, I love the way you picture Grendel (Figure 2) and that phenomenal idea of his seeing the victims be will devour as figures made of flesh, muscles, and tendons. How did you visualize it? Were there several steps or was it a visual idea you got quickly?

SG: David is quite quick in everything. Grendel's original design almost got unmodified to the final page. The idea of how Grendel sees his victims is totally David's.

DR: Everything was quite quick. I don't like to burn a lot energy before starting a project; I rather prefer to put all my energy on its implementation. I made a design of Grendel, with a bunch of ideas jotted down by it. I handed it to Santiago and he loved it; that was the guide to follow, without further previous revision. I wanted to picture monsters as just that: monsters. Entities of pure evil, not humanized beasts or evil humans. Monsters frighten us because we do not know their aims or the motivations of their deeds. And this ranges from Grendel and Ridley Scott's and H. R. Giger's Alien, to the primeval fear children have of monsters in the closet or under the bed. Showing how monsters see us is something that boosts such a feeling. Their gaze is devoid of any trace of humanity, empathy, or morals. We are only objects to them, things to play with, have sex with, or be eaten; or all at once. Only that. Nobody suffers when treading on an ant; that is the feeling I wanted to capture, highlight, and show with the "monster vision" in Beowulf. 


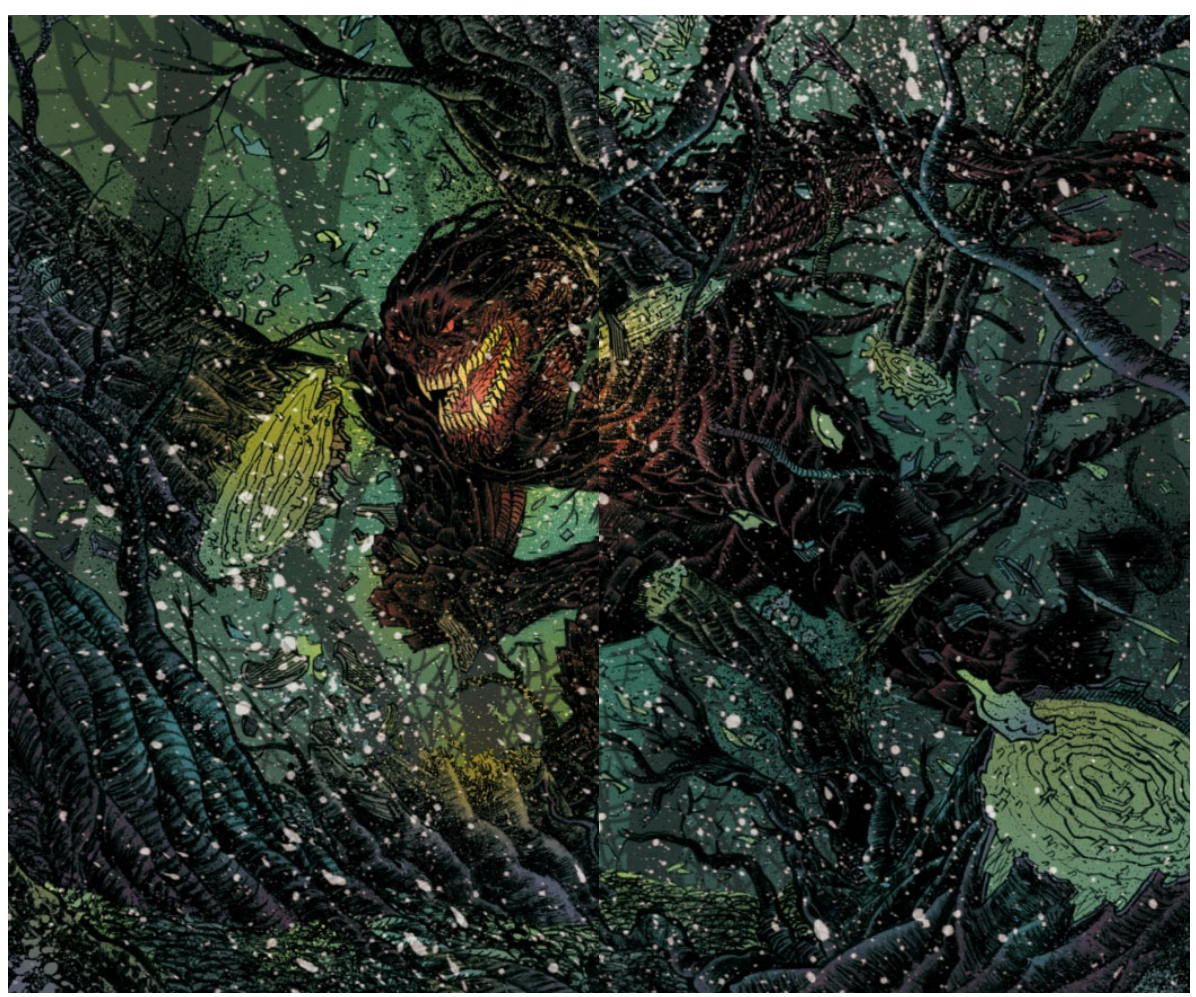

Figure 2. Grendel

Grendel's mother is also free from the typical female monster cliché. Visually, she resembles Grendel a great deal, a fact that is absent from many versions. Is this a conscious visual union of both characters? Grendel's mother also sees Beowulf as nothing but a bunch of flesh, muscles, and tendons.

SG: If you go to my original source, the version of the tale in Anne Terry White's Myths and Legends, you'll see how the Provensen represent the Mother with Grendel's exact features, adding only some items to denote the prototypical feminine shape, like clothing, and long hair. I think David and I saw Grendel and his mother as a doppelgänger, a twin monster you have to kill in two steps. Like a tumor you have to remove in a double surgery. You think one operation was enough, and then you discover later that some cancerous cells are still there. 
What fight was more difficult to present from a conceptual perspective? Grendel's? Or the underwater fight with bis mother?

SG: That's a question for David.

DR: The idea was to set the three fights (Dragon included) in a crescendo, with each fight being more spectacular than the previous one. Each has its own tempo, its own narrative games to play. This is similar to the way you play the final sections in videogames: each stage has to be more difficult than the previous you already passed; you have to adopt a different strategy to solve every step. This is what makes you to keep on playing the game and having fun with it. With this idea in mind I designed the fight scenes as set pieces.

The transition from Beowulf as a young victorious man to bis being an old King is also phenomenal. Jumping from "Their monster is gone" to "Yet monsters remain" constitutes a wonderful way of visualizing the fantastic fifty-year ellipsis the poem is so famous for. Your transition bighlights the idea of the permanence of monstrosity, of monsters among us all the time, right?

SG: Yes, that was the idea. We also wanted to keep the narrative monumental character of the poem. In a certain way, we wanted to update it without making it too modern, if you know what I mean. There is a manner of narration in Beowulf that has nothing to do whatsoever with contemporary narrative concepts. Instead of considering this a handicap and dodging the difference, we preferred to embrace it as an essential feature of the poem, as something productive we could enjoy.

DR: To me, reading the original poem is like watching an Etruscan statue. Very few are kept in one piece; but you see a fraction of a foot, of a torso, of a head, and you imagine the monumental character of the statue as a whole, the feeling of power it had to transmit to those who gazed on it in awe. We planned our work with this idea in mind.

This idea of inner monsters is also present in the cover (Figure 3). A very clear combination of both faces, buman and monstrous, almost like a filmic freeze-frame of a dissolve between two shots. 


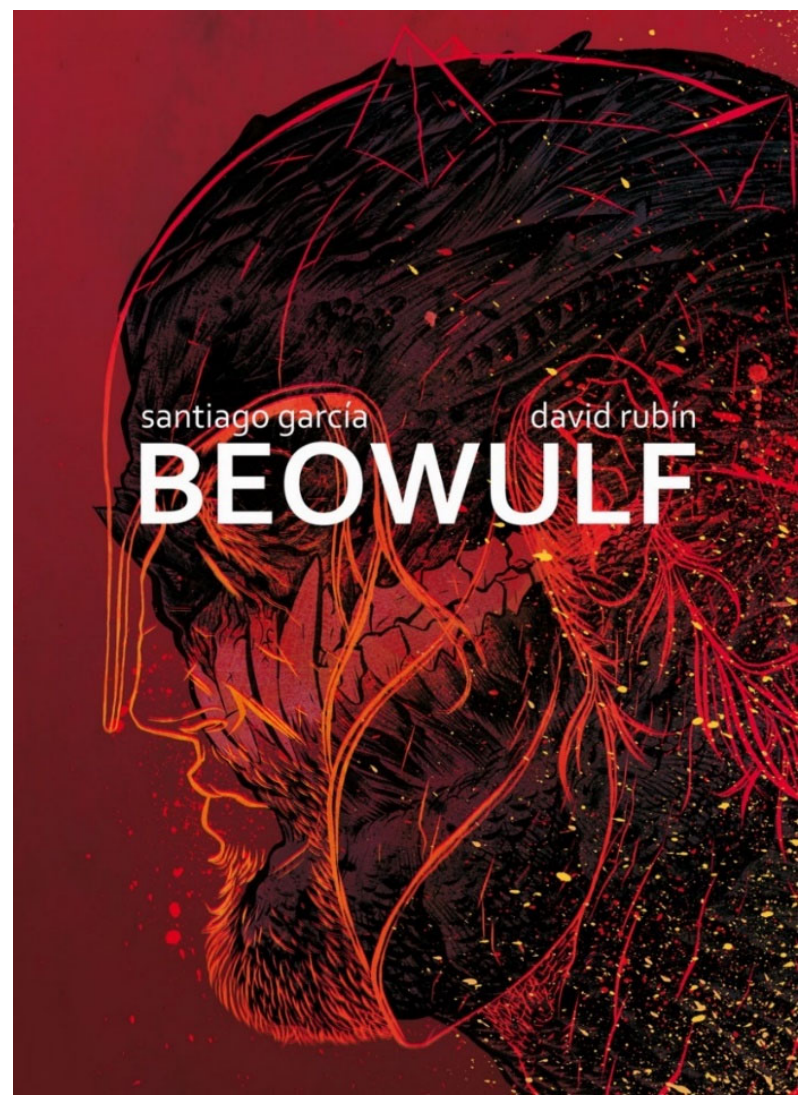

Figure 3. Cover

SG: Yes, the cover is one of the most brilliant designs David ever made. Beowulf and Grendel overlapping... It is a visual shock, full of meaning.

DR: Yes, it is simple and overwhelming. It is more a drawn idea than a cover with an embellishing or decorative function. That's why I think it worked so well. In France, our publishers (Casterman Bande Dessinée) insisted on replacing it and used something else. From the many countries in which the graphic novel was sold, France was the only one in which Beowulf didn't sell well. I rest my case... 
One of my favorite scenes from the end is that banquet presented with extreme closeups of our hero devouring some cherries wildly as be speaks with the poet about everlasting fame and the future remembrance of heroic deeds. Visually it is a great solution to picture the mundane and the heroic at the same time. Was it a clear visual solution for you too?

SG: It was an interpretation David made of the script, quite a successful one in my opinion, as it not only gives the text a cinematic quality but also strengthens it by presenting a close-up of Beowulf s fierce voracity; our hero, the one who will face the monster, is also a devouring monster himself.

DR: What Santiago says is exactly the reason why I wanted to avoid presenting Beowulf as "the knight who fights the dragon". I wanted to depict him as a decadent hero, more monster than heroic figure, someone who perceives his days are over and feels a demi-animal sense of extinction in the forthcoming battle, which he knows will be his last. Besides, it gives the sequence a very suitable sense of rhythm and tension.

Following this banquet scene, we see Old Man Beowulf trying to put his old coat of mail again, not without effort. This is a very clear visual topos of the classic superhero putting his/her suit back on after a long while. Was it intentional? It is an image the reader immediately acknowledges. Was it a simple and effective way of combining both literary worlds, mythology, and superheroes? All in all, every superhero story belongs to this adventure/mythological narrative tradition.

SG: Sure, Beowulf is a superhero; it is very easy to read the tale in such a way from our perspective. Both of us grew up with superhero comic books, so it is very easy for us to shed that light on any narrative we work with.

DR: That's exactly it. I recall we discussed the way to approach some scenes with a sentence like "we have to do something Marvel like, but without the Marvel thing". 
I enjoyed the way you also depart from more standard and overused habits when visualizing the dragon. It is very much visually connected with Grendel and his mother, an idea which reinforces the monstrous in every creature, right? Was this departure from prototypical dragons intentional? I think it was a total success, as it matched your style of re-storytelling the tale completely.

SG: I guess David can give a better answer to this.

DR: Yes, that was the idea, precisely: to offer a stylistic melt of all monsters. It is just like they all belong to the same race or species we can call, say, the "Monster Race", and inside such a race we had diversity in size, physiological features, and so on, according to each monster and its function in the scheme of things.

If I have to select only one section as an example of your Beowulf, I will undoubtedly choose the final eleven pages, which I recently revised with some detail (Bueno 2020: 127-128). Wiglaf states the ominous fate of the Geats as a consequence of Beowulfs death, and signals how they could disappear into oblivion. However, at the same time, the lower panel of the split page offers the sequence of the funeral pyre, with the first verses in Old English of the poem being recited as a background for the funeral (Figure 4). So, in a (almost cinematic) parallel structure, a rich density of visual content is shown: Wiglaf laments their fate, and Beowulfs body is burnt while the poem is sung. With the verses fresh in the air, a final solitary piece of ash vanishes into a pitch-black page, a very clear symbol of oblivion. Did you bave this approach clear in your minds from the start? That pitch black double page is such a symbol. Did you bave to fight hard for it with the publishers?

SG: The publishers always supported us in every detail, we never had to fight hard for anything, really. Half-way in the production process we decided to change the format and they went for it without discussion. So placing two pitch black double pages was not a problem. The ending tries to reproduce that funeral dirge feeling the poem transmits by using visual motifs. It is true that this parallel narrative appears at the beginning of our graphic novel, so the laws of symmetry favored an ending that was similar to the way we started our narrative. 


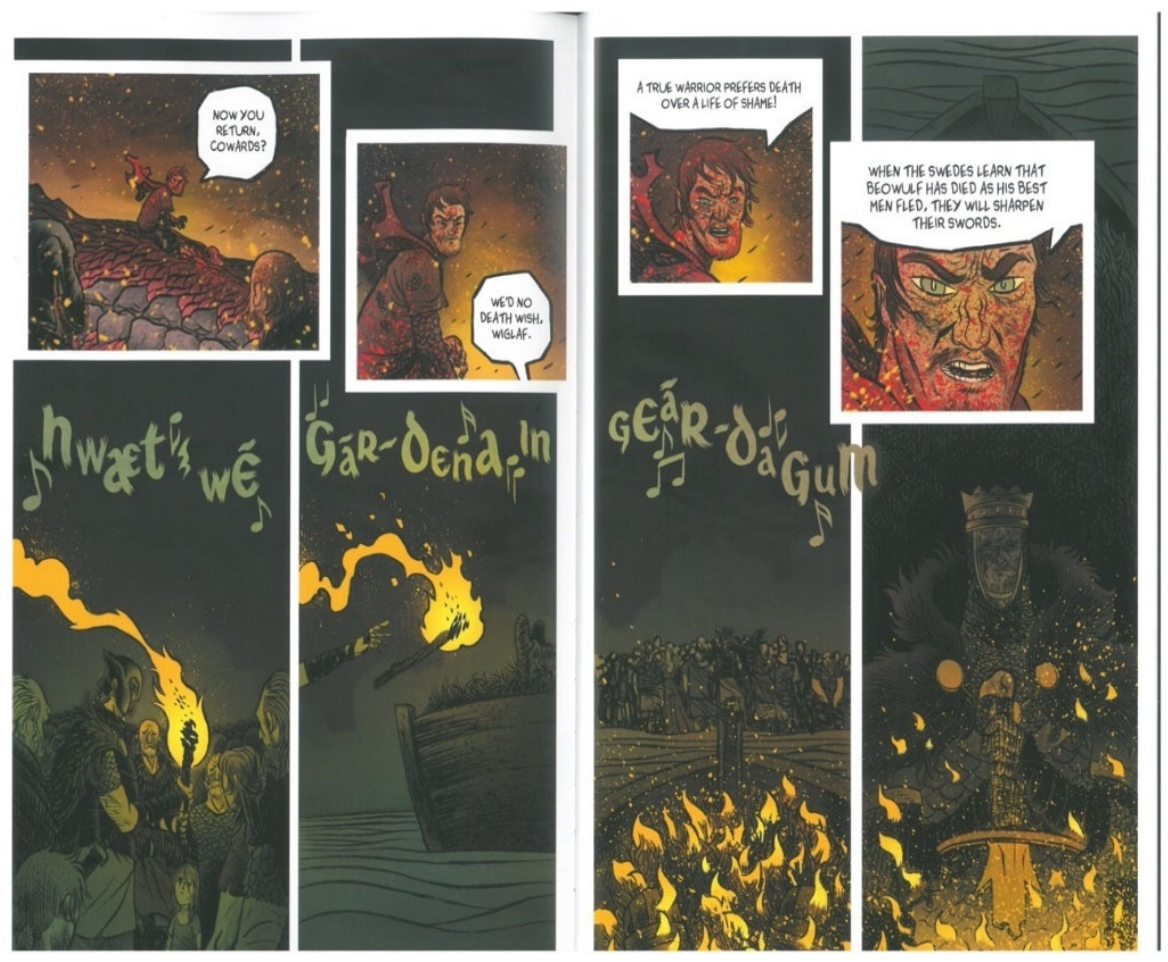

Figure 4. Beowulfs funeral

On the next page we see how oblivion is defeated as Beowulf's keenness for fame and remembrance finally triumphs. In a series of panels we see how the song and the verses sung at the funeral have survived in a manuscript, written by someone who remembers the deeds, and how from that manuscript a whole tradition of printed materials moves forward: manuscript, translation in printed form, script of a graphic novel, blackand-wbite sketches of that script, the finished colored page, the printing and binding of the graphic novel volumes, and, finally, in a wonderfully self-conscious metareference, a new reader grabbing a volume and reading the Beowulf story once again in this new format. It is such a perfect way to end the story. Was this ending something clear from the beginning, with this way of connecting the graphic novel form with the literary tradition that goes back to the original poem by acknowledging the importance of visual translation and adaptation, and adding the reader to that ongoing link? 
SG: Not at all. The whole sequence of the transformation of the poem into modern texts and into our own graphic novel was entirely David's idea. In fact, I was against that in the beginning. To me the ending lay just on the morphing of the funeral pyre into a sort of infinite bereavement. But David fought for the coda he really believed in, and we ended up by including it. These years have shown that this part is the best of the final section for many readers, so I have to prove him right in the end.

I have always thought that this tale of Beowulf has survived through many retellings and yours is one more in such a tradition, a new link in the storytelling trade. Graphic novels based on classic literature function like literary translations, as both belong to the same artistic effort to keep the story of Beowulffor contemporary audiences. What role do graphic novels play to get the reader hooked on reading similar literary texts or similar graphic novels? Do readers who have their first contact with Beowulf through your graphic novel tell you about reading the original story or other graphic novels of yours?

SG: In a case in which the original source is as remote as Beowulf (which by the way keeps on being adapted more or less accurately in contemporary media), I do not think we have a clear movement from the graphic novel to the old text. Let's say that Beowulf has transcended its original textual form and has turned into one of those myths one knows even without having read it, like Troy or the Flood story from the Bible. And precisely that is one of the most interesting aspects of the poem we wanted to deal with in our graphic novel: the movement from a mythical to a temporal tale, and how Beowulf is a liminal story at the crossroads of history and myth.

Stephen Tabachnik (2017: 2) said that graphic novels are "a form for all seasons", due to the richness of their narrative tools. In our case, in the classroom, students get immensely motivated when we teachers use graphic novels as an element for literary analysis/comparison. In recent years, I bad students who made their final BA or MA dissertations on topics based on Frank Miller, Neil Gaiman, Lovecraft-inspired videogames, and their links with other ways of narrating stories. We bave to fight hard for these topics in the academia because there are colleagues who still regard these works as 'minor art forms'. Do we really need to keep on defending graphic novels as a 'respected' form of artistic narrative? Is it not clear yet after all these past decades? 
SG: No, it is not clear because cultural customs and traditions change very slowly. Tastes and trends move in centuries. Roughly speaking, our society still accepts some values from the $19^{\text {th }}$ century as if they were still natural two hundred years later. There are "long history" cycles that take too much to be extinguished. This does not mean that there are no alternative trends which are more alive and could have the possibility of being hegemonic in the future. The way graphic novels are socially seen, perceived, and considered will change, and although the situation is much better than when David and I were kids there is still a lot of work to be done.

I do not want to conclude this interview without asking you about future work. Is there any literary-based new project ahead? I know DR is collaborating in the ongoing graphic novel series based on Neil Gaiman's Norse Mythology (Dark Horse, \#1 2020). Any future joint project you might advance to our readers? If you bad carte blanche and enough time, which literary classic would you like to adapt?

SG: More than carte blanche, which I always had when working on my graphic novels, what I would need is definitely more time and energy. There are tales from Classical and Germanic mythology I have always been fond of, like those of the Minotaur, Icarus, or Siegfried. It is no surprise if I tell you that these were also included in Anne Terry White's Mytbs and Legends. Besides, one of my most recent works deals with such issues: La Cólera (2020), which I did with Javier Olivares, presents the figure of Achilles through The Iliad and The Odyssey.

\section{References}

Bueno, J. L. 2020: The Monsters, the Translators, and the Artists: lofgeornost and the Challenges of Translating Beowulf. In D. Clark ed. Beowulf in Contemporary Culture. Newcastle, Cambridge Scholars Publishing: 111-133.

Bueno, J. L. 2021: "Retelling Old Stories for New Audiences": Shaping and Visualizing Beowulf through Gareth Hinds' Graphic Novels [The Collected Beowulf (2003) and Beowulf (2007)]. In S. C. Thomson ed. Medieval Stories and Storytelling: Multimedia and Multi-temporal Perspectives (Medieval Narratives in Transmission Series, 2). Turnhout, Brepols Publishers: 53-70.

Eco, U. 1999: Apocalípticos e integrados. Barcelona, Lumen.

García, S. \& J. Olivares 2020: La Cólera. Bilbao, Astiberri Ediciones. 
García, S. \& D. Rubín 2013: Beowulf. Bilbao, Astiberri Ediciones. [2016, Berkeley, CA, Image Comics, Inc., 3rd ed., 2020]

Haydock, N. \& E. L. Risden 2013: Beowulf on Film: Adaptations and Variations. Jefferson, NC, McFarland \& Company Publishers, Inc.

Heaney, S. trans. 1999: Beowulf: A Verse Translation. London, Faber and Faber.

Hinds, G. 2007: Beowulf. Cambridge, MA, Candlewick Press.

Kindt, M. \& D. Rubín 2017: Ether 1. Death of the Last Golden Blaze. Milwaukie, OR, Dark Horse Comics [La muerte de la última llama dorada. Bilbao, Astiberri Ediciones].

Kindt, M. \& D. Rubín 2019: Ether 2. The Copper Golems. Milwaukie, OR, Dark Horse Comics [Los Golems de cobre. Bilbao, Astiberri Ediciones].

Kindt, M. \& D. Rubín 2020: Ether 3. The Dissappearance of Violet Bell. Milwaukie, OR, Dark Horse Comics [ $\mathrm{La}$ desaparición de Violeta Campana. Bilbao, Astiberri Ediciones].

Rubín, D. 2011: El héroe. Libro 1. Bilbao, Astiberri Ediciones. [2015: The Hero. Book 1. Milwaukie, OR, Dark Horse Comics]

Rubín, D. 2012: El héroe. Libro 2. Bilbao, Astiberri Ediciones. [2015: The Hero. Book 2. Milwaukie, OR, Dark Horse Comics]

Stern, S. L. \& C. Steininger 2007: Beowulf: The Graphic Novel. Barnet, Hertfordshire, Markosia Enterprises.

Storrie, P. D. \& R. Randall 2008: Beowulf, Monster Slayer. A British Legend. Minneapolis, MN, Graphic Universe (Lerner Publishing Group).

Tabachnik, S. E. 2017: The Cambridge Companion to the Graphic Novel. Cambridge, Cambridge University Press.

\author{
Author's address \\ Department of English, French and German \\ University of Vigo \\ Lagoas-Marcosende Campus \\ Praza das Cantigas, s/n \\ E36310 VIGO (Spain) \\ e-mail: jlbueno@uvigo.es
}

received: 30 May 2021

revised version accepted: 15 June 2021 